\title{
Clinical characteristics and prediction model of long-term survival of patients with stage III non-small cell lung cancer
}

\author{
Jun Zhang, Deruo Liu \\ Department of Thoracic Surgery, Peking University China-Japan Friendship School of Clinical Medicine, Beijing, China \\ Contributions: (I) Conception and design: All authors; (II) Administrative support: D Liu; (III) Provision of study materials or patients: All authors; (IV) \\ Collection and assembly of data: J Zhang; (V) Data analysis and interpretation: J Zhang; (VI) Manuscript writing: All authors; (VII) Final approval of \\ manuscript: All authors. \\ Correspondence to: Deruo Liu. Department of Thoracic Surgery, Peking University China-Japan Friendship School of Clinical Medicine, No. 2, East \\ Yinghua Street, Chaoyang District, Beijing 100029, China. Email: deruoliu@163.com.
}

\begin{abstract}
Background: The patients with stage III non-small cell lung cancer own a poor prognosis. We aimed to study the clinical characteristics of the patients with stage III non-small cell lung cancer and more than 5 years overall survival and establish a prognosis prediction model.

Methods: A total of 5792 patients were separated from the Surveillance, Epidemiology, and End Results database between 2011 and 2015. Cox regression was performed to select the predictors of overall survival. The validation of the nomogram was implemented by using the concordance index, calibration curves. Kaplan-Meier curves were used to illustrate and compare the overall survival of patients in different clinical characteristics.

Results: Multivariate analyses indicated factors such as age, sex, site, histology, grade, stage T, and N, surgical treatment were associated with prognosis. In the nomogram, we could predict the probability of overall survival for patients. The concordance index of the novel nomogram was 0.751 . The calibration curves also showed good consistency in the probability of 5-year overall survival. The Kaplan-Meier curves showed that overall survival in the different age, sex, race, site, histology, grade, stage $\mathrm{T}$ and $\mathrm{N}$, surgical treatment was accurately differentiated with a significantly statistical difference

Conclusions: Patients with a highly differentiated adenocarcinoma and early stages of $\mathrm{T}$ and $\mathrm{N}$ who are less than 70 years of age and have an opportunity for surgery to undergo surgery have a higher five-year survival rate in patients with stage III non-small cell lung cancer.
\end{abstract}

Keywords: Lung cancer; stage III; adenocarcinoma; nomogram

Submitted Oct 29, 2020. Accepted for publication Jan 06, 2021.

doi: $10.21037 /$ tcr-20-3173

View this article at: http://dx.doi.org/10.21037/tcr-20-3173

\section{Introduction}

Lung cancer is the most common cancer and the leading cause of cancer death in the world, which has the highest morbidity and mortality of malignant tumors (1). The number of deaths from lung cancer is larger than the sum of the breast, colon, and prostate cancer (2). In the pathological type of lung cancer, non-small cell lung cancer accounts for $80-85 \%$ and $30 \%$ of non-small cell lung cancer patients have already arrived at stages III at diagnosis with an unsatisfactory prognosis $(3,4)$. At present, the research on the prognosis of stage III non-small cell lung cancer patients is mainly focused on its treatment, such as surgical method, radiotherapy and chemotherapy, immunotherapy, and so on. However, the study that focuses on the clinical characteristics of the patients with stage III non-small cell lung cancer which may influence the prognosis is relatively less. The purpose of our study is to study the clinical characteristics of the patients with stage III non-small cell lung cancer patients with more than 5 years of overall 
survival and establish a prognosis prediction model (5-7). We present the following article in accordance with the TRIPOD reporting checklist (available at: http://dx.doi. org/10.21037/tcr-20-3173).

\section{Methods}

\section{Study population}

SEER 18 population-based cancer Registries (1975 to 2017 dataset) were chosen to select patients, which is maintained by the National Cancer Institute and covers nearly $28 \%$ of the population in the United States. The inclusion criteria in our study were that (I) patients with stage III non-small cell lung cancer were diagnosed between 2010 and 2015; (II) patients aged 18 years or older who were diagnosed; (III) the information of patient consisted of the age of diagnosis, race, sex, primary site, laterality, stage $\mathrm{T}$, stage $\mathrm{N}$, grade, histology, surgery, survival status and time. Individuals who had unclear information were subsequently excluded. We collected and retrospectively analyzed the demographic data of all eligible cases.

The study was conducted in accordance with the Declaration of Helsinki (as revised in 2013). This article does not contain any studies with human participants or animals performed by any of the authors. All procedures performed in study involving human data were extracted freely from the SEER Research Data available to the public online (https://seer.cancer.gov/data/access.html).

\section{Statistical analysis}

The analysis of differences in clinical characteristics between the different groups was performed by using the chi-square test. An analysis of Cox regression was implemented to assess the risk factors of overall survival. It was set up in that $\mathrm{P}<0.05$ was considered statistically significant. R software was used to set up a nomogram based on the numerous possible prognostic factors which could be associated with the overall survival. The validation of the nomogram was executed, and the results were evaluated based on the concordance index and the calibration curve. The concordance index was used to denote the predictive accuracy and differentiation ability of each factor of the nomogram. Calibration curves were performed to check the calibration of the nomogram. Kaplan-Meier curves were used to illustrate and compare the overall survival of patients in different clinical characteristics. Data extraction was collected using SEER ${ }^{*}$ Stat software version 8.3.6.1 and data analyses were all performed using $\mathrm{R}$ software (version 4.0.0).

\section{Results}

\section{Demographics of the entire cohort of patients}

Overall, 5,792 patients with stage III non-small cell lung cancer were included among which 2,963 $(51.16 \%)$ patients were diagnosed at the age of $\geq 70$ years. Males accounted for $53.94 \%$ and the majority of patients were white $(79.70 \%)$ which is related to the fact that the United States is a white-dominated country. In terms of the primary site, the percentages of the upper lobe and lower lobe were $64.93 \%$ and $30.27 \%$ respectively. For the laterality, the right tumors $(58.34 \%)$ were the most common and the pathology of adenocarcinoma (53.49\%) had a higher proportion than the squamous-cell carcinoma. For the grade, the grade II and grade III had a higher proportion $(38.42 \%$ and $53.45 \%$ ). Based on the AJCC guidelines for the staging of tumor nodule metastasis (TNM), T2, T3, and T4 had a higher proportion than T1. For lymph nodes, N2 (63.17\%) was the most common. Only 1,898 (32.77\%) of those patients underwent surgery (Table 1).

\section{Cox regression analysis for estimating the risk factors of overall survival}

The Cox proportional hazards model was performed to investigate how each variable could help predict overall survival. Multivariate analyses indicated that factors such as age, sex, site, histology, grade, stage $\mathrm{T}$, and $\mathrm{N}$, chemoradiotherapy, surgical treatment were associated with the prognosis of patients (Table 2).

\section{Building and validating the novel nomogram}

The model that incorporated the above factors was developed and presented as the nomogram (Figure 1). In the nomogram, each predictor was scored based on a point scale. By adding up the total scores projected in the scale at the bottom, we could then predict the probability of overall survival for patients with stage III non-small cell lung cancer. The concordance index of the novel nomogram was 0.751 , indicating the good discrimination ability of the model. The calibration curves also showed good consistency in the probability of 5 -year overall survival between the 
Table 1 Clinicopathologic characteristics of the entire cohort of patients

\begin{tabular}{|c|c|c|}
\hline Characteristics & Number & $\%$ \\
\hline \multicolumn{3}{|l|}{ Age } \\
\hline$<70$ & 2,829 & 48.84 \\
\hline$\geq 70$ & 2,963 & 51.16 \\
\hline \multicolumn{3}{|l|}{ Sex } \\
\hline Female & 2,668 & 46.06 \\
\hline Male & 3,124 & 53.94 \\
\hline \multicolumn{3}{|l|}{ Race } \\
\hline Black & 679 & 11.72 \\
\hline White & 4,616 & 79.70 \\
\hline Other & 497 & 8.58 \\
\hline \multicolumn{3}{|l|}{ Site } \\
\hline Upper lobe & 3,761 & 64.93 \\
\hline Middle lobe & 278 & 4.80 \\
\hline Lower lobe & 1,753 & 30.27 \\
\hline \multicolumn{3}{|l|}{ Laterality } \\
\hline Left & 2,413 & 41.66 \\
\hline Right & 3,379 & 58.34 \\
\hline \multicolumn{3}{|l|}{ Histology } \\
\hline Squamous-cell carcinoma & 2,694 & 46.51 \\
\hline Adenocarcinoma & 3,098 & 53.49 \\
\hline \multicolumn{3}{|l|}{ Grade } \\
\hline Grade I; Well differentiated & 420 & 7.25 \\
\hline Grade II; Moderately differentiated & 2,225 & 38.42 \\
\hline Grade III; Poorly differentiated & 3,096 & 53.45 \\
\hline Grade IV; Undifferentiated; anaplastic & 51 & 0.88 \\
\hline \multicolumn{3}{|l|}{ Stage-T } \\
\hline T1 & 768 & 13.26 \\
\hline $\mathrm{T} 2$ & 1,724 & 29.77 \\
\hline T3 & 1,520 & 26.24 \\
\hline $\mathrm{T} 4$ & 1,780 & 30.73 \\
\hline \multicolumn{3}{|l|}{ Stage-N } \\
\hline No & 715 & 12.34 \\
\hline N1 & 663 & 11.45 \\
\hline $\mathrm{N} 2$ & 3,659 & 63.17 \\
\hline N3 & 755 & 13.04 \\
\hline
\end{tabular}

Table 1 (continued)
Table 1 (continued)

\begin{tabular}{lcc}
\hline Characteristics & Number & $\%$ \\
\hline Chemotherapy & & \\
No/unknow & 2,427 & 41.90 \\
Yes & 3,365 & 58.10 \\
Radiotherapy & & \\
No/unknow & 3,624 & 62.57 \\
Yes & 2,168 & 37.43 \\
Surgery & & \\
Yes & 1,898 & 32.77 \\
No & 3,894 & 67.23 \\
\hline
\end{tabular}

actual observation and the nomogram prediction (Figure 2).

\section{Kaplan-Meier curves of overall survival for patients}

The Kaplan-Meier curves showed that overall survival in the different age, sex, race, histology, grade, stage $T$, and $\mathrm{N}$, chemoradiotherapy, surgical treatment was accurately differentiated with a significantly statistical difference (Figure 3).

\section{Demographics of the patients with different overall survival}

The significant difference in race, site, laterality was not found between the two groups. There was a significantly lower proportion of patients with the age of $\geq 70$ years in the group with the overall survival of more than 5 years $(\mathrm{P}<0.001)$. The demographic and clinicopathologic characteristics like male, squamous-cell carcinoma were in the same way. However, the group with the overall survival of more than 5 years demonstrated a significantly higher proportion of patients with surgery. The group with the overall survival of more than 5 years had a higher proportion of well-differentiated tumors (grade I + grade II) $(50.42 \%$ vs. $45.12 \%)$ as same as the stage $\mathrm{T} 1$ and $\mathrm{N} 0$ (Table 3).

\section{Discussion}

Non-small cell lung cancer is one of the most common types of lung cancer originating from alveolar epithelium 
Table 2 Cox regression analysis for estimating the risk factors of overall survival

\begin{tabular}{|c|c|c|c|}
\hline Characteristics & $\mathrm{HR}$ & $95 \% \mathrm{Cl}$ of $\mathrm{HR}$ & $P$ value \\
\hline \multicolumn{4}{|l|}{ Age } \\
\hline$<70$ & \multicolumn{3}{|l|}{ Reference } \\
\hline$\geq 70$ & 1.382 & $1.300-1.450$ & $<0.001$ \\
\hline \multicolumn{4}{|l|}{ Sex } \\
\hline Female & \multicolumn{3}{|l|}{ Reference } \\
\hline Male & 1.210 & $1.138-1.287$ & $<0.001$ \\
\hline \multicolumn{4}{|l|}{ Race } \\
\hline Black & \multicolumn{3}{|l|}{ Reference } \\
\hline White & 1.043 & $0.949-1.174$ & 0.381 \\
\hline Other & 0.877 & $0.763-1.007$ & 0.063 \\
\hline \multicolumn{4}{|l|}{ Site } \\
\hline Upper lobe & \multicolumn{3}{|l|}{ Reference } \\
\hline Middle lobe & 1.000 & $0.861-1.162$ & 0.998 \\
\hline Lower lobe & 1.104 & $1.033-1.180$ & 0.004 \\
\hline \multicolumn{4}{|l|}{ Laterality } \\
\hline Left & \multicolumn{3}{|l|}{ Reference } \\
\hline Right & 0.982 & $0.923-1045$ & 0.567 \\
\hline \multicolumn{4}{|l|}{ Histology } \\
\hline $\begin{array}{l}\text { Squamous-cell } \\
\text { carcinoma }\end{array}$ & \multicolumn{3}{|l|}{ Reference } \\
\hline Adenocarcinoma & 0.870 & $0.8224-0.935$ & $<0.001$ \\
\hline \multicolumn{4}{|l|}{ Grade } \\
\hline $\begin{array}{l}\text { Grade I; Well } \\
\text { differentiated }\end{array}$ & \multicolumn{3}{|l|}{ Reference } \\
\hline $\begin{array}{l}\text { Grade II; Moderately } \\
\text { differentiated }\end{array}$ & 1.171 & $1029-1.333$ & 0.017 \\
\hline $\begin{array}{l}\text { Grade III; Poorly } \\
\text { differentiated }\end{array}$ & 1.308 & $1.153-1.485$ & $<0.001$ \\
\hline $\begin{array}{l}\text { Grade IV; } \\
\text { Undifferentiated; } \\
\text { anaplastic }\end{array}$ & 1.275 & $0.907-1.793$ & 0.162 \\
\hline \multicolumn{4}{|l|}{ Stage-T } \\
\hline $\mathrm{T} 1$ & \multicolumn{3}{|l|}{ Reference } \\
\hline $\mathrm{T} 2$ & 1.187 & $1.071-1317$ & 0.001 \\
\hline T3 & 1.289 & $1.154-1.436$ & $<0.001$ \\
\hline $\mathrm{T} 4$ & 1.356 & $1.209-1.521$ & $<0.001$ \\
\hline
\end{tabular}

Table 2 (continued)
Table 2 (continued)

\begin{tabular}{lrrr}
\hline Characteristics & HR & $95 \%$ Cl of HR & P value \\
\hline Stage-N & & & \\
N0 & Reference & & \\
N1 & 1.205 & $1.047-1.387$ & 0.009 \\
N2 & 1.279 & $1.139-1.436$ & $<0.001$ \\
N3 & 1.352 & $1.180-1.550$ & $<0.001$ \\
Chemotherapy & & & \\
No/unknow & Reference & & \\
Yes & 2.321 & $2.212-2.567$ & $<0.001$ \\
Radiotherapy & & & \\
No/unknow & Reference & \\
Yes & 2.203 & $2.102-2.473$ & $<0.001$ \\
Surgery & & & \\
Yes & Reference & \\
No & 2.193 & $2.032-2.367$ & $<0.001$ \\
\hline
\end{tabular}

or bronchial mucosal epithelium. However, the exact mechanism remains unclear. Moreover, more than $30 \%$ of patients with non-small cell lung cancer are diagnosed at advanced stages with a limited survival rate. The 5 -year survival rate of stage III non-small cell lung cancer is from the range of $13 \%$ to $36 \%$ and the survival time is reduced when distant metastases occur (8). It has been widely accepted that surgery, chemotherapy, and radiotherapy are significant for patients with non-small cell lung cancer at advanced stages. The study that focuses on the clinical characteristics of stage III non-small cell lung cancer patients which may influence the prognosis is relatively less. In the present study, therefore, we have incorporated a total of 5,792 patients diagnosed with stage III non-small cell lung cancer using the SEER database to address the abovementioned issue.

According to the global health statistics, $50 \%$ of nonsmall cell lung cancer patients were over 65 years old when they were first diagnosed and more than $30 \%$ of non-small cell lung cancer patients were 70 years old. The function of various organs of the body will be significantly reduced when patients are over 70 years old. Patients aged over 70 have their unique characteristics of pathology, physiology, and metabolism. Therefore, it has been a consensus to 


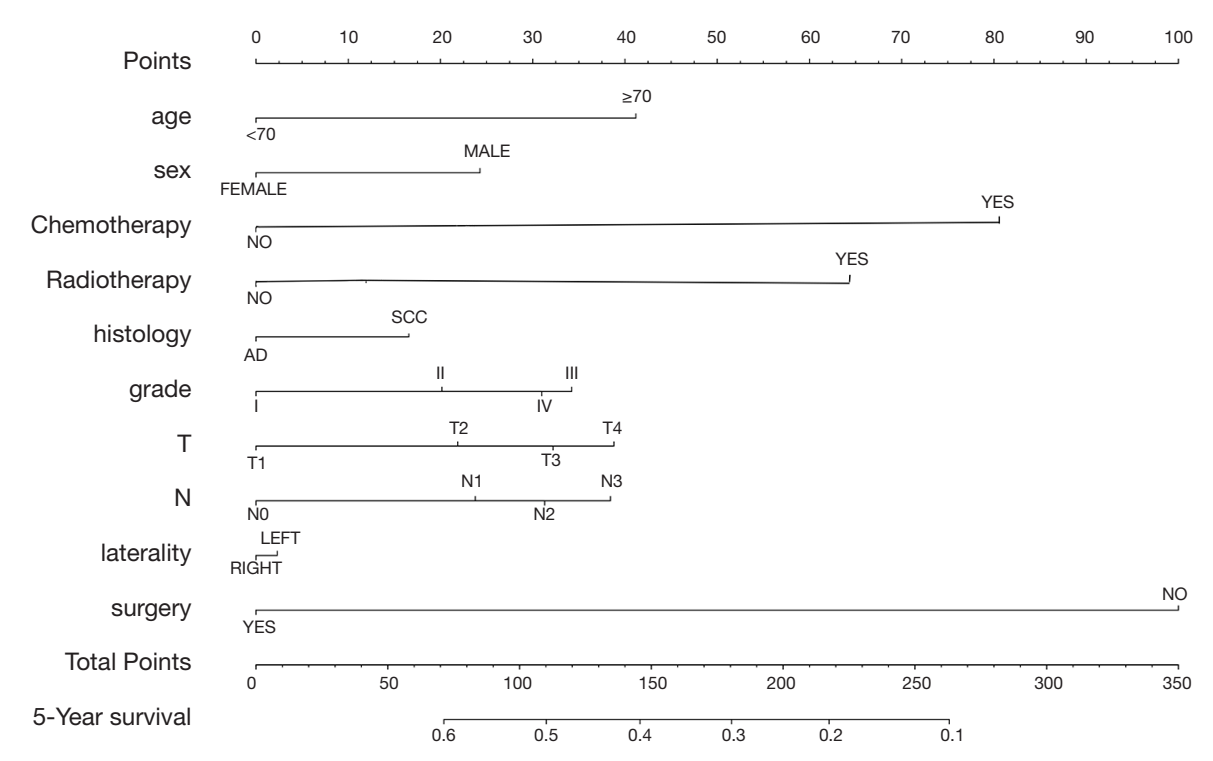

Figure 1 Nomogram to predict the overall survival of patients with stage III non-small cell lung cancer.

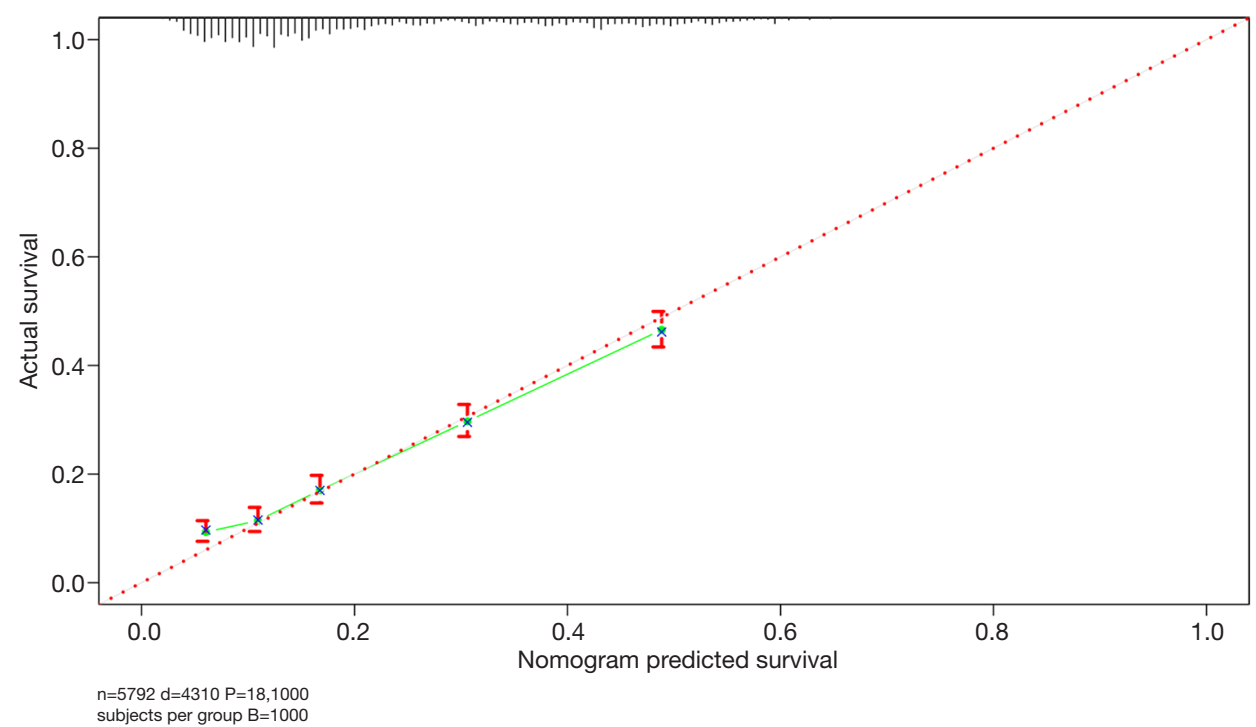

Figure 2 Calibration curve showing nomogram-predicted overall survival compared with the actual overall survival.

define non-small cell lung cancer patients aged $\geq 70$ as elderly non-small cell lung cancer patients (9). The study of Ping showed that the median survival time of patients with lung cancer was 22.17 months in the young group $(<50)$ and 20.15 months in the old group (>70). The cumulative survival time of the young group was better than that of the old group, but there was no statistically significant $(\mathrm{P}>0.05)(10)$. Mauri et al. also suggested that the prognosis of young lung cancer patients was similar to that of old lung cancer patients (11). However, some studies had shown that younger patients with lung cancer have a better prognosis, which is consistent with our study $(12,13)$.

The reported studies had demonstrated that women with non-small cell lung cancer had a better prognosis than men with longer survival (14-16). Foeglé and colleagues found that there was no gender difference by retrospectively analyzing the outcomes of 1,738 non-small cell lung cancer patients (17). However, in our study, the 5 -year survival 

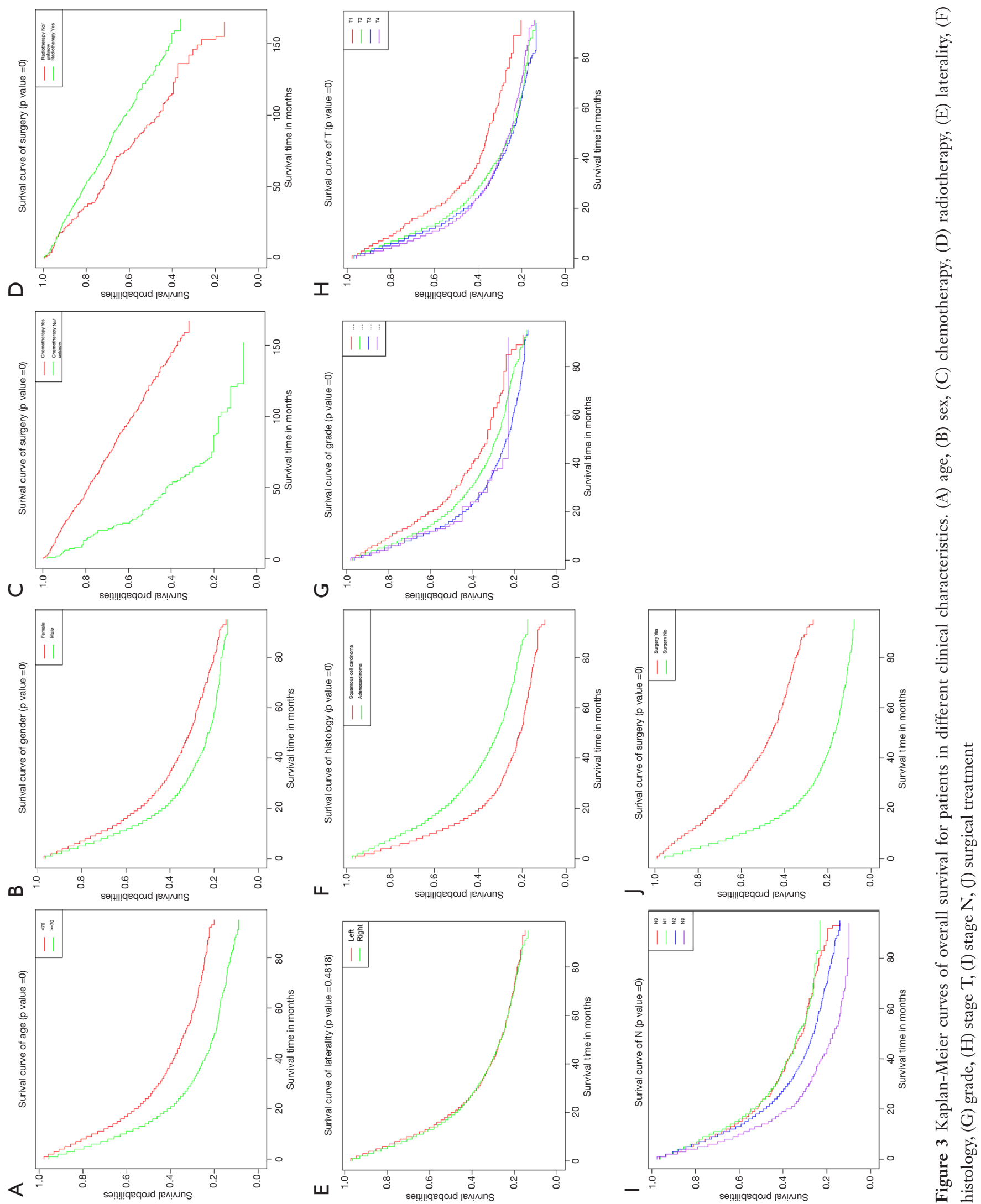
Table 3 Demographic and clinicopathologic characteristics of different overall survival

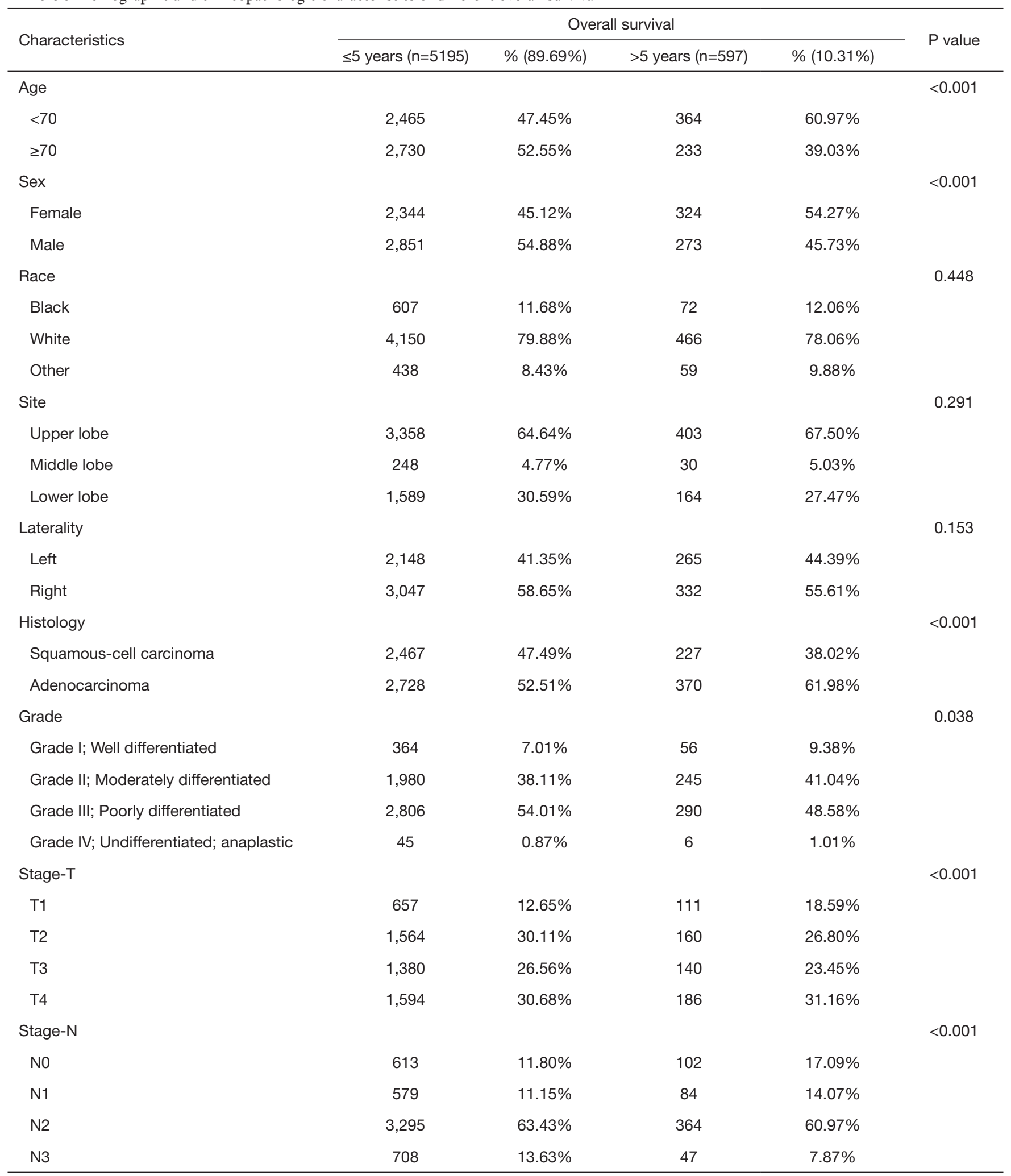

Table 3 (continued) 
Table 3 (continued)

\begin{tabular}{|c|c|c|c|c|c|}
\hline Characteristics & \multicolumn{4}{|c|}{ Overall survival } & $P$ value \\
\hline Chemotherapy & & & & & $<0.001$ \\
\hline No/unknow & 3,110 & $59.87 \%$ & 212 & $35.51 \%$ & \\
\hline Yes & 2,085 & $40.13 \%$ & 385 & $64.49 \%$ & \\
\hline No/unknow & 3,542 & $68.18 \%$ & 200 & $36.52 \%$ & \\
\hline Yes & 1,653 & $31.82 \%$ & 379 & $63.48 \%$ & \\
\hline Surgery & & & & & $<0.001$ \\
\hline Yes & 1,527 & $29.39 \%$ & 371 & $62.14 \%$ & \\
\hline
\end{tabular}

of female patients with adenocarcinoma was significantly higher than that of male patients with squamous cell carcinoma patients, which might mean that adenocarcinoma had a better prognosis than squamous cell carcinoma. The significant difference of 5 -year survival in age, sex, race, site, histology, grade, stage $\mathrm{T}$, and $\mathrm{N}$, chemoradiotherapy, surgical treatment was also found in the presented study except race, site, and laterality.

Multimodality therapy is an appropriate treatment approach for stage III non-small cell lung cancer patients. But the optimal treatment strategies are still indistinct. When surgical resection can be accomplished after adjuvant therapy with low risk and a good chance of complete resection, the survival time may be optimal. Despite the lack of information on chemoradiotherapy, we were still able to see that surgery could improve the prognosis of patients with stage III non-small cell lung cancer and there was a higher rate of surgical treatment among those with a survival of more than 5 years compared with those with the survival of less than 5 years. The results of our study are consistent with that of some previous studies (18).

There still are some several limitations that deserve attention in our study. First, because the study is a retrospective study, it will have an unavoidable confounding bias. Second, the details of chemotherapy and radiotherapy are not obtained in the SEER database, which hindered further prognostic analyses. Third, the population of our study was patients in America, which can not represent the global population. Finally, because the external validation was not accomplished, before the proposed nomogram can be used in clinical practice, it needs to be replicated and verified prospectively.

\section{Conclusions}

In conclusion, age, sex, histology, grade, stage $\mathrm{T}$, and $\mathrm{N}$, chemoradiotherapy, surgical treatment are associated with a 5 -year survival of a patient with stage III non-small cell lung cancer. We constructed and validated a novel nomogram with relatively good accuracy to help predict 5 -year overall survival for a patient with stage III non-small cell lung cancer. Clinicians can predict individualized survival and give treatment recommendations by using the prognostic model.

\section{Acknowledgments}

We thank Steven Wong for providing language editing assistance in this study.

Funding: None.

\section{Footnote}

Reporting Checklist: The authors have completed the TRIPOD reporting checklist. Available at http://dx.doi. org/10.21037/tcr-20-3173

Data Sharing Statement: Available at http://dx.doi. 
org/10.21037/tcr-20-3173

Conflicts of Interest: Both authors have completed the ICMJE uniform disclosure form (available at http://dx.doi. org/10.21037/tcr-20-3173). The authors have no conflicts of interest to declare.

Ethical Statement: The authors are accountable for all aspects of the work in ensuring that questions related to the accuracy or integrity of any part of the work are appropriately investigated and resolved. The study was conducted in accordance with the Declaration of Helsinki (as revised in 2013). This article does not contain any studies with human participants or animals performed by any of the authors. All procedures performed in study involving human data were extracted freely from the SEER Research Data available to the public online (https://seer.cancer.gov/ data/access.html).

Open Access Statement: This is an Open Access article distributed in accordance with the Creative Commons Attribution-NonCommercial-NoDerivs 4.0 International License (CC BY-NC-ND 4.0), which permits the noncommercial replication and distribution of the article with the strict proviso that no changes or edits are made and the original work is properly cited (including links to both the formal publication through the relevant DOI and the license). See: https://creativecommons.org/licenses/by-nc-nd/4.0/.

\section{References}

1. Siegel RL, Miller KD, Jemal A. Cancer statistics, 2019. CA Cancer J Clin 2019;69:7-34.

2. Kanitkar AA, Schwartz AG, George J, et al. Causes of death in long-term survivors of non-small cell lung cancer: A regional Surveillance, Epidemiology, and End Results study. Ann Thorac Med 2018;13:76-81.

3. Mosmann MP, Borba MA, de Macedo FP, et al. Solitary pulmonary nodule and (18)F-FDG PET/CT. Part 1: epidemiology, morphological evaluation and cancer probability. Radiol Bras 2016;49:35-42.

4. Goldstraw P, Chansky K, Crowley J, et al. The IASLC Lung Cancer Staging Project: Proposals for Revision of the TNM Stage Groupings in the Forthcoming (Eighth) Edition of the TNM Classification for Lung Cancer. J Thorac Oncol 2016;11:39-51.
5. Tabchi S, Kassouf E, Rassy EE, et al. Management of stage III non-small cell lung cancer. Semin Oncol 2017;44:163-77.

6. Watanabe SI, Nakagawa K, Suzuki K, et al. Neoadjuvant and adjuvant therapy for Stage III non-small cell lung cancer. Jpn J Clin Oncol 2017;47:1112-8.

7. Bobbili P, Ryan K, Duh MS, et al. Treatment patterns and overall survival among patients with unresectable, stage III non-small-cell lung cancer. Future Oncol 2019;15:3381-93.

8. American Cancer Society. Non-small cell lung cancer survival rates, by Stage (2017). Available online: www. cancer.org/cancer/non-small-cell-lung-cancer/detectiondiagnosis-staging/survival-rates.html

9. Chen H, Ren J, Che M, et al. Diagnosis and treatment of lung cancer in the elderly. Geriatrics \& Health Care 2005;01:37-38, 60.

10. Ping D, Yang S, Cheng Z, et al. The Surgical Treatment and Prognosis in Elderly with Non-small Cell Lung Cancer. Chinese Journal of Clinical Thoracic and Cardiovascular Surgery 2009;16:14-8.

11. Mauri D, Pentheroudakis G, Bafaloukos D, et al. Nonsmall cell lung cancer in the young: a retrospective analysis of diagnosis, management and outcome data. Anticancer Res 2006;26:3175-81.

12. Rich AL, Khakwani A, Free CM, et al. Non-small cell lung cancer in young adults: presentation and survival in the English National Lung Cancer Audit. QJM 2015;108:891-7.

13. Lara MS, Brunson A, Wun T, et al. Predictors of survival for younger patients less than 50 years of age with nonsmall cell lung cancer (NSCLC): a California Cancer Registry analysis. Lung Cancer 2014;85:264-9.

14. Wheatley-Price P, Blackhall F, Lee SM, et al. The influence of sex and histology on outcomes in non-smallcell lung cancer: a pooled analysis of five randomized trials. Ann Oncol 2010;21:2023-8.

15. Xu QP, He P, Liu ZQ, et al. Effect of gender on the prognosis of patients with non-small cell lung cancer. Zhonghua Liu Xing Bing Xue Za Zhi 2017;38:244-7.

16. Gao Y, Zhou X. Analysis of clinical features and prognostic factors of lung cancer patients: A population-based cohort study. Clin Respir J 2020. [Epub ahead of print]. doi: 10.1111/crj.13188.

17. Foeglé J, Hédelin G, Lebitasy MP, et al. Specific features of non-small cell lung cancer in women: a retrospective 
study of 1738 cases diagnosed in Bas-Rhin between 1982 and 1997. J Thorac Oncol 2007;2:466-74.

18. Eberhardt W, Bildat S, Korfee S, et al. Preoperative

Cite this article as: Zhang J, Liu D. Clinical characteristics and prediction model of long-term survival of patients with stage III non-small cell lung cancer. Transl Cancer Res 2021;10(3):14391448. doi: $10.21037 /$ tcr-20-3173 treatment strategies in stage III non-small cell lung cancer. Lung Cancer 2001;33 Suppl 1:S51-9. 